\title{
PEMBERDAYAAN DAN PENINGKATAN KESEJAHTERAAN MASYARAKAT PETANI PEKEBUN DENGAN PENGOLAHAN HASIL PERTANIAN/PERKEBUNAN, UMKM DAN PEMBELAJARAN MELALUI KKN-PPM DI DESA MALLONGI-LONGI KABUPATEN PINRANG
}

\author{
Nur Anny S Taufieq ${ }^{1}$, Wahidah Sanusi ${ }^{2)}$ \\ 1)Jurusan Pendidikan Teknik Bangunan, Universitas Negeri Makassar \\ ${ }^{2)}$ Jurusan Matematika, Universitas Negeri Makassar \\ $e$-mail $:{ }^{1)}$ nurannytaufieq@yahoo.co.id
}

\begin{abstract}
ABSTRAK
Kegiatan KKN-PPM dilaksanakan di tiga dusun yang ada di Desa Mallongi-longi, Kabupaten Pinrang. Tujuan kegiatan ini adalah: a) Mengoptimalkan diversifikasi dengan pengelohan hasil perkebunan dan pertanian menjadi berbagai produk jadi; b) Mengolah hasil tani/kebun menjadi berbagai produk yang bernilai ekonomis; c) Dapat membuat kemasan dan pemasaran produk hasil pertanian/perkebunan;d) Pembentukan dan pemberdayaan masyarakat dalam UMKM e) Menciptakan masyarakat bebas putus sekolah, buta huruf, buta baca Qur'an dan buta aksara di wilayah KKN-PPM; f) Meningkatkan Kesadaran akan pentingnya kesehatan bagi anak, guru dan orang tua di lingkungan sekolah dan rumah; dan g) Mengoptimalkan peranan masyarakat dalam bidang pendidikan dan kesehatan. Permasalahan mitra adalah: a) Hasil pertanian/perkebuanan dijual dengan hasil yang sangat murah; b) Kurangnya pemahaman masyarakat dalam mengolah hasil pertanian/perkebunan menjadi produk jadi bernilai ekonomis; c) Belum maksimalnya pengetahuan masyarakat tentang UMKM; d) Banyaknya anak usia 6 s/d 12 tahun putus sekolah dan yang tidak bersekolah; e) Kurangnya kesadaran masyarakat tentang pentingnya kesehatan; f) rendahnya pendidikan non-formal; g) Rendahnya motivasi anak-anak dan orang tua tentang pentingnya pendidikan. Metode yang digunakan adalah melakukan penyuluhan, memberikan pelatihan olah hasil perkebunan menjadi produk jadi bernilai ekonomis seperti keripik terong, baruasa, manisan, dll., Tudang Sipulung, pendidikan dan pengajaran non-formal kepada anak putus sekolah selama pelaksanaan kegiatan, pendampingan pembentukan UMKM dan penyuluhan dan sosialisasi tentang pentingnya kesehatan dengan menciptakan lingkungan rumah dan sekolah yang bersih. Luaran yang diharapkan adalah: 1) Meningkatkan keterampilan masyarakat dalam membuat berbagai produk jadi hasil perkebunan, 2) Meningkatkan kesadaran, wawasan, motivasi, kemampuan, keterampilan dan perilaku anak-anak putus sekolah dan siswa, 3) Menciptakan masyarakat bebas buta huruf dan aksara serta bebas anak-anak putus sekolah 4) Meningkatkan Kualitas pendidikan Dasar dengan pembimbingan, pembelajaran tambahan, Cerdas Cermat dan pengajaran baca Qur'an, 5) Perbaikan sistem pada kelompok petani/pekebun dengan UMKM; 6) Publikasi ilmiah, teknologi tepat guna dan produk olahan hasil pertanian/perkebunan seperti Barongko dan Nugget Terong.
\end{abstract}

Kata Kunci : Home schooling, UMKM, Barongko dan Nugget Terong

\section{PENDAHULUAN}

\section{Analisis Situasi}

Desa Mallongi-Longi yang menjadi target lokasi KKN-PPM berjarak $21 \mathrm{~km}$ dari ibukota kabupaten Pinrang dan merupakan salah satu dari 7 desa/kelurahan yang ada di Kecamatan Lanrisang Kabupaten Pinrang dengan 95 persen penduduk di desa ini hidup sebagai Petani/Pekebun.

Peningkatan mutu dan kualitas produksi hasil pertanian dan perkebunan di Desa Mallongi-Longi Kabupaten Pinrang memerlukan upaya keras dengan sinergisme yang tinggi dari berbagai pihak. Berdasarkan hasil observasi diketahui bahwa permasalahan yang dihadapi dalam bidang pertanian/perkebunan adalah pengembangan sarana dan prasarana perkebunan, serta teknologi untuk mendukung peningkatan produksi dan produktifitas belum maksimal; alih fungsi lahan pertanian ke non pertanian masih cukup tinggi; biaya produksi tidak sebanding dengan harga jual dimana hasil panen mereka hanya dijual perkarung dengan harga sangat murah seperti pada Gambar 1 (harga terong dijual 
Rp.35.000/karung), padahal jika dijual perbuah Rp.2000 maka satu karung bisa dijual Rp.150.000, apalagi kalau hasil kebun ini diolah menjadi produk siap jual seperti kerupuk, manisan, dll. Kemudian belum optimalnya manajemen agrebisnis; pengembangan penyediaan sarana prasarana, teknologi dan kelembagaan untuk mendukung peningkatan produksi dan produktifitas serta nilai tambah hasil perkebunan; juga degradasi hutan dan lahan; alih fungsi lahan; luas hutan semakin

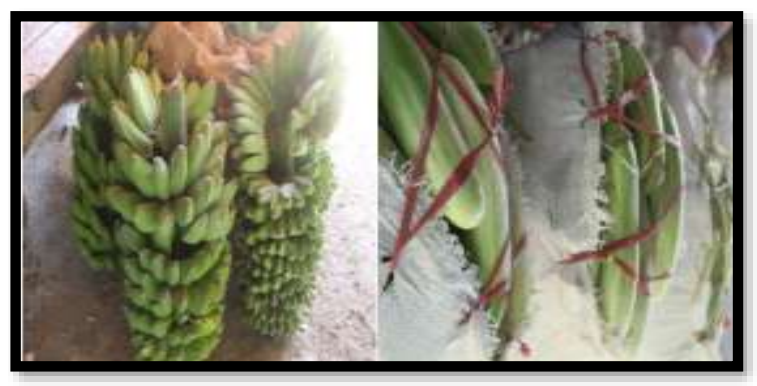

Gambar 1. Pisang dan Terong hasil kebun yang dijual sangat murah berkurang akibat dari penambangan; luas lahan kritis masih cukup banyak.

\section{PERMASALAHAN DAN PENYELESAIAN PERMASALAHAN WILAYAH}

Berdasarkan permasalahan di wilayah KKN-PPM yang dimaksud di atas, maka penyelesaian permasalahan disajikan dalam tabel 1 berikut:

\begin{tabular}{|c|c|c|}
\hline No. & Permasalahan Wilayah & Solusi Permasalahan \\
\hline 1. & $\begin{array}{l}\text { Belum optimalnya diversifikasi produk pangan } \\
\text { local }\end{array}$ & $\begin{array}{l}\text { Mengoptimalkan diversifikasi dengan } \\
\text { pengelohan hasil perkebunan dan pertanian } \\
\text { menjadi berbagai produk jadi }\end{array}$ \\
\hline 2. & $\begin{array}{l}\text { Ketersedian dan kedaulatan pangan belum } \\
\text { menjadi fokus daerah }\end{array}$ & Sosialisasi dengan pemerintah setempat \\
\hline 3. & $\begin{array}{l}\text { Kesadaran masyarakat mengkonsumsi produk } \\
\text { pangan lokal cenderung menurun }\end{array}$ & $\begin{array}{l}\text { Sosialisasi dan pelatihan produk jadi hasil } \\
\text { perkebunan }\end{array}$ \\
\hline 4. & $\begin{array}{l}\text { Ketidakberdayaan masyarakat disebabkan } \\
\text { faktor ekonomi, rendahnya kapasitas SDM, dan } \\
\text { terbatasnya akses informasi, sarana, modal, } \\
\text { pasar dan pelayanan }\end{array}$ & $\begin{array}{l}\text { Sosialisasi dan pelatihan olahan hasil } \\
\text { pertanian menjadi produk jadi bernilai } \\
\text { ekonomis dan pemasaran }\end{array}$ \\
\hline 5. & $\begin{array}{l}\text { Kurangnya pengetahuan masyarakat dalam } \\
\text { mengelola hasil perkebunan menjadi produk } \\
\text { bernilai ekonomis }\end{array}$ & $\begin{array}{l}\text { Pelatihan pengolahan hasil tani/kebun } \\
\text { menjadi berbagai produk yang bernilai } \\
\text { ekonomis }\end{array}$ \\
\hline 6. & $\begin{array}{l}\text { Inovasi dan adopsi teknologi, pengembangan } \\
\text { desain produk, yang berdampak pada } \\
\text { diversifikasi masih rendah }\end{array}$ & $\begin{array}{l}\text { Pelatihan pengemasan dan pemasaran } \\
\text { produk hasil pertanian/perkebunan }\end{array}$ \\
\hline 7. & $\begin{array}{l}\text { Jaringan pasar industry kecil dan kemitraan } \\
\text { dalam usaha pemasaran masih terbatas }\end{array}$ & Pembentukan UMKM di lokasi KKI \\
\hline 8. & $\begin{array}{l}\text { Belum maksimal Pemberdayaan koperasi } \\
\text { UMKM untuk meningkatkan pertumbuhan } \\
\text { ekonomi berkualitas dan berkelanjutan }\end{array}$ & $\begin{array}{l}\text { Memaksimalkan pemberdayaan koperasi } \\
\text { UMKM }\end{array}$ \\
\hline 9. & $\begin{array}{l}\text { Belum fokus dan tidak sinerginya gerakan } \\
\text { pemberdayaan masyarakat yang dilaksanakan } \\
\text { antara pemerintah, permkab dan desa }\end{array}$ & $\begin{array}{l}\text { Pemberdayaan masyarakat dalam } \\
\text { mengolah hasil pertanian/perkebunan di } \\
\text { wilayah KKN-PPM }\end{array}$ \\
\hline 10. & $\begin{array}{l}\text { Masih tingginya angka buta aksara serta angka } \\
\text { partispasi sekolah cenderung menurun }\end{array}$ & $\begin{array}{l}\text { Memberikan pembelajaran kepada anak } \\
\text { putus sekolah dan pembelajaran tambahan } \\
\text { untuk anak sekolah }\end{array}$ \\
\hline 11. & $\begin{array}{l}\text { Rendahnya Pendidikan non-formal dengan } \\
\text { banyakanya anak usia sekolah yang tidak } \\
\text { bersekolah dan anak-anak putus sekolah. }\end{array}$ & $\begin{array}{l}\text { Memaksimalkan berbagai } \text { program } \\
\text { pembelajaran tambahan, baik pelajaran } \\
\text { sekolah maupun pelajaran baca Qur'an }\end{array}$ \\
\hline 12. & $\begin{array}{l}\text { Rendahnya tingkat kesadaran orang tua dalam } \\
\text { bidang pendidikan agama. }\end{array}$ & Sosialisasi dan pembelajaran baca Alqur"an \\
\hline 13. & $\begin{array}{l}\text { Standar pelayanan minimal pendidikan belum } \\
\text { tercapai }\end{array}$ & $\begin{array}{l}\text { Memaksimalkan pelayanan dalam bidang } \\
\text { pendidikan }\end{array}$ \\
\hline 14. & $\begin{array}{l}\text { Tingginya pengaruh negatif media terhadap } \\
\text { permbentukan kepribadian anak }\end{array}$ & $\begin{array}{l}\text { Sosialisasi dan penyuluhan pengaruh positif } \\
\text { dan negatif teknologi }\end{array}$ \\
\hline 15. & $\begin{array}{l}\text { Belum optimalnya aksesibilitas, sarana dan } \\
\text { prasarana dan peran serta masyarakat dalam } \\
\text { penyelenggaraan pendidikan }\end{array}$ & $\begin{array}{l}\text { Mengoptimalkan peranan } \\
\text { dalam bidang pendidikan }\end{array}$ \\
\hline
\end{tabular}


Adapun cara pemberdayaan masyarakat agar kegiatan berkelanjutan adalah dengan melibatkan kelompok tani, orang tua/siswa/guru, aparat pemerintahan dan masyarakat sehingga berbagai kegiatan dan solusi yang ditawarkan dapat dilanjutkan, misalnya produk jadi terus diproduksi dan selanjutnya peningkatan kualitas dan perbaikan kemasan, kemudian pengurusan ijin dari depkes dan halal dari MUI dapat dilanjutkan pada kegiatan KKN-PPM selanjutnya di desa Mallongi-Longi Kabupaten Pinrang.

\section{METODE KEGIATAN}

Teknologi dan metode yang akan digunakan dalam pelaksanaan KKN-PPM adalah:

\section{Pertanian dan Perkebunan}

Pengelohan hasil pertanian/perkebunan dan pembentukan UMKM menjadi target utama di bidang pertanian dan perkebunan pada pelaksanaan KKN-PPM yang berupa:

a. Pemanfaatan lahan sangat penting dalam meningkatkan hasil panen baik dari segi kulaitas maupun kuantitasnya apalagi masyarakat terkadang belum memanfaatkan tanah perkebunan dengan maksimal di Desa Mallongi-Longi.

b. Memberikan pelatihan olah hasil perkebunan menjadi produk jadi bernilai ekonomis seperti keripik terong, baruasa, manisan, dll. Kegiatan ini dilakukan mengingat pengetahuan masyarakat tentang pengolahan bahan baku menjadi produk bernilai ekonomis masih sangat kurang.

c. Pelatihan pengemasan produk.

d. Pendampingan pembentukan UMKM, karena masyarakat memang belum terlalu memahami UMKM.

\section{Pendidikan dan Pembelajaran}

Pendidikan dan pembelajaran juga menjadi target utama di bidang pendidikan, baik formal maupun non-formal.

Pendidikan dan pembelajaran tersebut berupa:

a. Pembelajaran langsung di satu tempat bagi anak-anak putus sekolah dan belum lancar baca tulis. b. Pembelajaran tambahan bagi siswa SD dan SMP dalam rangka peningkatan kualitas pendidikan bagi siswa.

c. Menghidupkan motivasi siswa Sekolah Dasar dangan kempetisi intern sekolah dan mengundang SD dari desan lain di tingkat kecamatan.

3. Kesehatan dan Lingkungan

Penyuluhan kesehatan dan pemanfaatan lingkungan juga menjadi target utama dalam bidang kesehatan dan lingkungan dengan memberikan penyuluhan kesehatan kolaborasi antara dinas kesehatan dan pelaksana KKN-PPM.

4. Penyuluhan

Metode yang digunakan adalah:

1. Metode duduk bersama dengan masyarakat dan keluarga petani/pekebun, kemudian melakukan diskusi kelompok dan umpan balik dengan memberikan kesempatan kepada mereka untuk menyampaikan tanggapan, pendapat, atau saran mengenai masalah dan penyelesaian masalah.

2. Metode Demonstrasi/pelatihan, yaitu langsung ke masyarakat memberikan pelatihan cara mengolah hasil pertanian/perkebunan menjadi produk jadi bernilai ekonomis seperti keripik, manisan, baruasa, dan lain-lain.

3. Metode Demonstrasi/pelatihan pengemasan produk.

4. Metode penyuluhan langsung tentang bahaya penyakit menular dan pentingnya kesehatan lingkungan.

\section{HASIL DAN PEMBAHASAN}

\section{Pelaksanaan Kegiatan}

Kegiatan pertama yang dilakukan pada KKNPPM ini adalah sosialisasi kegiatan masing-masing di Jurusan Pendidikan Teknologi Pertanian, Matematika dan Ekonomi selama tiga hari yaitu pada tanggal 3, 7 dan 10 April 2017. Tujuan sosialisasi ini adalah menjelaskan program secara umum dan tujuan dan perbedaan KKN-PPM dan KKN reguler sekaligus merekrut peserta. Setelah kegiatan ini akhirnya didapatkan mahasiswa-mahasiswi yang akan mengikuti program KKN-PPM ini. Kegiatan 
selanjutnya adalah pembekalan selama 4 kali yaitu tanggal 17 April, 24 April, 1 Mei dan 21 Mei 2017. Kegiatan ini menguraikan dan menjelaskan tahapan program secara detail kepada peserta sehingga mahasiswa sebagai pelaksana program dapat mengetahui dan memahami kegiatan yang akan mereka laksanakan di lokasi. Kegiatan pembekalan ini juga sudah membagi peserta menjadi lima kelompok sesuai dengan jumlah lokasi KKN-PPM, mereka juga sudah mengetahui tanggungjawab masing-masing. Kegiatan selanjutnya adalah melakukan sosialisasi ke lokasi KKN-PPM, dimana Tim pelaksana bersama koordinatorkoordinator melakukan kunjungan lokasi pada tanggal 6 Juni 2016 untuk bertemu dengan aparat pemerintahan setempat seperti Camat, Lurah/Desa dan masyarakat di Desa Mallongi-Longi Kabupaten Pinrang untuk mensosialisasikan program setelah peserta berada di lokasi KKN-PPM.

Adapun hasil kegiatan program kerja yang dilakukan oleh mahasiswa KKN-PPM UNM tahun 2017 dari tanggal 12 Juli sampai 19 Agustus 2017.

1) Pengolahan Hasil Pertanian

Program kerja yang diberi nama Pemberdayaan dan Peningkatan Kesejahteraan Masyarakat Petani/Pekebun dengan Pengolahan Hasil Pertanian/Perkebunan, UMKM dan Pembelajaran Melalui KKN/PPM Di Desa Mallongi-Longi, Kecamatan Lanrisang, Kabupaten Pinrang atau bisa disebut pengolahan hasil pertanian merupakan program kerja utama yang dilaksanakan oleh mahasiswa KKN-PPM UNM 2017 di setiap desa yang menjadi lingkup kerja. Yang menjadi tolak ukur persentase keberhasilan program kerja ini adalah jumlah peserta yang ditargetkan serta kemampuan pengolahan yang diterima oleh ibu-ibu peserta, kami memberikan target 20 peserta yang akan menghadiri program kerja tersebut namun nyatanya yang sempat menghadiri hanya sampai 17 peserta. Hal-hal yang mempengaruhi jumlah peserta yang hadir diantaranya karena pada tanggal 5 Agustus 2017 saat pelaksanaan pengolahan hasil pertanian bertepatan dengan pelatihan bagi perangkat desa di kantor Desa Mallongi-Longi yang juga merupakan sebagian besar warga yang diundang pada program kerja tersebut, selain itu terdapat kesalahpahaman informasi yang diterima oleh panitia masjid yang menyampaikan pengumuman undangan pengolahan terong dan pisang kepada masyarakat melalui masjid dengan menganggap program kerja yang akan dilaksanakan adalah pelatihan penanaman terong dan pisang.

Namun disamping itu jika diperhatikan dari antusias warga yang datang, para ibu-ibu terlihat bersemangat untuk mempelajari resep yang telah dibagikan oleh mahasiswa KKN dan berinisiatif untuk mencoba lebih jauh tentang pengolahan hasil pertanian terong dan pisang tersebut. Semoga kegiatan serupa dapat dilaksanakan di Desa Mallongi-Longi dengan jenis produk pengolahan yang lebih bervariatif.

2) Pendidikan Non-Formal

a) Pelajaran Tambahan

Pembelajaran tambahan merupakan program kerja pendidikan Non-Formal yang dilaksanakan di 3 sekolah yang berada Desa Mallongi-Longi. Program kerja ini terbagi atas 3 yakni Pembelajaran Ujian Nasional (UN), Pembelajaran Cerdas Cermat, dan Pembelajaran umum. Berikut ini merupakan penjabaran dari 3 hal diatas:

\section{- Pembelajaran Ujian Nasional (UN)}

Meskipun ujian nasional terbilang masih berlangsung beberapa bulan ke depan namun, kami dari peserta KKN-PPM 2017 Desa Mallongi-Longi, hal ini dilakukan guna mengulang pembelajaran kelas 4- 5 untuk siswa kelas 6. Hal ini disambut baik oleh guru dan siswa di masing-masing dilihat dari keaktifan siswa dalam mengikuti proses pembelajaran, meskipun hanya dilakukan beberapa kali di masing-masing sekolah.

\section{- Pembelajaran Cerdas Cermat}

Program kerja kecamatan yakni Lomba cerdas cerdas merupakan awal dari ide teman-teman untuk melakukan proses pembelajaran cerdas cermat, meskipun beberapa kali sempat tertunda bahkan terancam tidak terlaksana, namun pembelajaran cerdas cermat tetap berjalan hingga perlombaan cerdas cermat di 
Kecamatan. Peserta pembelajaran ini berjumlah 9 orang di masing-masing sekolah yang kemudian diseleksi untuk mewakili setiap sekolah mengikuti lomba cerdas cermat Kecamatan Lanrisang. Jadwal yang semula hanya dilaksanakan 2 kali dalam satu Minggu yakni Rabu (Bahasa Indonesia dan Matematika) serta Sabtu (IPA dan IPS) berjalan dengan baik, akan tetapi mendekati jadwal perlombaan di setiap sekolah dilakukan pemadatan jadwal yakni di masing-masing sekolah dilaksanakan pada sore dan pagi hari.

- Pembelajaran umum

Pelajaran tambahan ketiga yakni pembelajaran umum seperti belajar membaca dan berhitung. Program kerja ini dilaksanakan di Posko 1 dan Posko 2 Desa Mallongi-Longi secara bergantian. Pembelajaran dilaksanakan tidak terjadwal namun beberapa kali dilaksanakan pada malam hari ba'da Magrib dan setelah pulang sekolah. Meskipun peserta pembelajaran tidak banyak namun siswa tampak semangat bila mengikuti proses pembelajaran.

- Pelajaran Mengaji

Program kerja ini memberikan bimbingan dan pembelajaran Al-Qur'an kepada anakanak yang tinggal di sekitar Masjid Nurul Yaqin Paladang yang merupakan masjid terdekat dari posko KKN-PPM UNM 2017 (rumah kepala desa Mallongi-Longi). Pelajaran mengaji ini menggunakan metode Iqra. Peserta yang pada awalnya hanya diikuti oleh 6 orang yang dilaksanakan ba'da magrib, kemudian pada hari berikutnya jadwal dipindahkan menjadi ba'da Ashar dan peserta bertambah menjadi 12 orang, hari berikutnya jadwal kembali dipindahkan mengingat jadwal mengikuti pelaksanaan TPA oleh guru mengaji dan peserta bertambah pesat menjadi 32 orang alhasil kami kekurangan pengajar. Pada hari-hari berikutnya diikuti rata-rata oleh 15 peserta. Mendekati perayaan 17 -an pembelajaran mengaji terhenti karena padatnya jadwal dari peserta.
3) Pendidikan Formal

Program kerja pendidikan formal ialah program kerja yang bergelut pada bidang pendidikan di sekolah yang terbagi menjadi dua bagian utama, yaitu memberikan pengajaran bagi siswa-siswi di setiap SD Desa Mallongi-Longi pada jam pelajaran sekolah, dan memberikan pelatihan untuk persiapan lomba dalam rangka Hari Ulang Tahun Republik Indonesia (HUT RI) ke-72 yang dilaksanakan di dusun Ulo, Desa Samaulue, Kecamatan Lanrisang. Berikut adalah penjabaran kedua hal diatas:

a) Pembelajaran Formal di Kelas

Pembelajaran ini dilaksanakan di setiap sekolah dasar (SD) di Desa Mallongi-Longi. Pembelajaran yang diambil yakni Matematika dan Ilmu Pengetahuan Sosial (IPS) hal ini mengingat peserta KKN PPM 2017 Desa Mallongi-Longi rata-rata adalah berbasis dari 2 mata pelajaran tersebut. Adapun kelas yang diambil yaitu: SD 71 Siporennu: kelas V dengan 13 siswa dan dilaksankan pada hari kamis; SD 69 Paladang: Kelas IV dan SD 60 Ujung: Kelas V.

b) Pelatihan Persiapan Perlombaan 17-an

Pelatihan yang diberikan meliputi lomba gerak jalan, lagu solo, lagu kor, kasidah rebana, tarian tradisional, voli, sepak bola, sepak takraw, serta berbagai lomba yang dilaksanakan selama perayaan HUT RI ke-72 di Desa Samaulue. Program kerja ini dapat dikatakan terlaksana untuk setiap Sekolah Dasar yang ada di Desa Mallongi-Longi, hanya saja yang menjadi faktor penghambat adalah jarak sekolah dengan posko KKN-PPM UNM 2017 cukup jauh, terlebih jarak ke SDN 204 Ujung.

4) Sosialisasi Program Kerja

Sosialisasi program kerja dilaksanakan pada pekan pertama sejak tiba di lokasi pelaksanaan KKN-PPM UNM 2017, sosialisasi ini berjalan dengan lancar dan dapat terselesaikan dalam pekan pertama tersebut. Sosialisasi yang dilaksanakan selama 3 hari ini dilakukan dengan berkunjung ke beberapa rumah penduduk setempat untuk bersilaturahmi dan memperkenalkan beberapa program kerja yang akan dilaksanakan selama masa KKN selain itu, 
sosialisasi ini juga dilakukan untuk mengajak masyarakat setempat menghadiri program kerja utama (Pengolahan Hasil Pertanian) yang dilaksanakan pada tanggal 5 Agustus 2017.

5) Pembuatan Tempat Sampah

Pembuatan tempat sampah adalah program kerja tambahan KKN-PPM UNM 2017 Desa MallongiLongi, pelaksanaan program kerja ini pertama-tama dimulai dengan mengumpulkan bahan-bahan untuk membuat tempat sampah, yaitu balok, papan, dan bambu yang merupakan bahan utamanya. Pembuatan tempat sampah ini memakan waktu kurang lebih 2 pekan hingga proses pengecatan. Program kerja ini terlaksana dengan cukup baik serta dapat terselesaikan tepat pada waktunya. Tempat sampah yang dibuat adalah sebanyak 9 buah dan ditempatkan di SDN 60 Ujung, SDN 69 Paladang, dan kedua posko KKN-PPM UNM 2017 Desa Mallongi-Longi.

\section{6) Pembuatan Jembatan di TK PPLP PGRI Paladang}

Pembuatan jembatan untuk TK PPLP PGRI Paladang adalah program kerja tambahan yang dibuat atas permintaan dari Taman Kanak-Kanak tersebut, program kerja ini berjalan dengan lancar dan dapat terselesaikan dengan cepat, hanya membutuhkan waktu selama 1 hari. Pembuatan jembatan ini sepenuhnya ditanggung oleh pihak taman kanakkanak, terkhusus pada alat dan bahannya sehingga mahasiswa KKN-PPM UNM 2017 Desa MallongiLongi hanya memberikan bantuan tenaga untuk pembuatannya.

7) Pembuatan Peta Penggunaan Lahan Desa Mallongi-Longi

Program kerja ini adalah program kerja tambahan yang dilaksanakan sesuai dengan kesepakatan pada rapat perdana peserta KKN PPM 2017 Desa Mallongi-Longi. Pembuatan peta ini dapat terselesaikan sebelum penarikan dan ditempatkan di kantor Desa Mallongi-Longi.

8) Pemberian Makanan Tambahan untuk Posyandu

Program kerja pemberian makanan tambahan untuk anak balita dilaksanakan pada tanggal 24 Juli 2017. Program kerja ini dilaksanakan di dua posyandu yang ada di dua dusun berbeda Desa Mallongi-Longi, yaitu di Dusun Siporennu dan
Dusun Paladang. Selain memberikan makanan tambahan, program kerja ini juga membantu petugas posyandu melancarkan kegiatan tersebut.

9) Pembersihan Lingkungan

Pembersihan lingkungan adalah program kerja yang pertama dilakukan oleh peserta KKN PPM 2017 Desa Mallongi-Longi. Dilaksanakan pada hari Jumat dan Hari Ahad di 4 masjid di Desa Mallongi-Longi (Masjid Al-Hidayah Siporennu, Masjid Nurul Yaqin Paladang, Masjid Jabal Rahmah Ujung, dan Masjid Al-Falah Ujung) yang sempat terlaksana selama 2 pekan berturut-turut yaitu pada tanggal 14 dan 21 Juli 2017 serta pembersihan kantor Desa MallongiLongi yang dilaksanakan satu kali pada hari Ahad 23 Juli 2017.

\section{KESIMPULAN}

Kegiatan program KKN-PPM ini dilaksanakan pada tiga dusun di Desa Mallongi-Longi Kabupaten Pinrang selama 5 bulan mulai bulan April hingga bulan Agustus 2015. Inti pelaksanaan kegiatan ini adalah melaksanakan kegiatan-kegiatan yang sudah terprogram dan dilakukan oleh mahasiswa kepada masyarakat di lokasi KKN-PPM dan didampingi oleh Tim KKN-PPM. Kegiatan ini bertujuan untuk meningkatkan wawasan dan pengetahuan masyarakat mengenai pengolahan hasil kebun (Terong dan Pisang) menjadi produk jadi bernilai ekonomis, kemampuan dan wawasan keilmuan bagi anak putus sekolah dan pemuda di lokasi KKN-PPM.

\section{REFERENSI}

Bappeda. 2015. Badan Perencanaan Pembangunan daerah Kabupaten Pinrang.

Bappeda Kabupaten Pinrang, 2012 http://bisnisukm.com

Cyio, M.B. 2008. Efektivitas bahan organik dan tinggi genangan terhadap perubahan $\mathrm{Eh}, \mathrm{pH}$, dan status Fe, P, Al terlarut pada tanah ultisol. Jurnal Agroland 15 (4): 257-263.

Dahlan \& Prayogi, A.Z. 2008. Pengaruh jarak tanam berganda terhadap pertumbuhan dan produksi tanaman jagung. Jurnal Agrisistem 4 (2): 101108.

Danial, M., Taufieq, Nur Anny S. \& Sanusi, W. 2008. Pemanfaatan zeolit dan bokashi ampas tahu untuk menekan konsentrasi nikel dan 
meningkatkan pertumbuhan baby corn pada tanah tambang di Soroako. Penelitian Hibah Bersaing Tahun Pertama. Lembaga Penelitian Universitas Negeri Makassar. Makassar.

Danial, M., Taufieq, Nur Anny S. \& Sanusi, W. 2009. Pemanfaatan zeolit dan bokashi ampas tahu untuk menekan konsentrasi nikel dan meningkatkan pertumbuhan baby corn pada tanah tambang di Soroako. Penelitian Hibah Bersaing Tahun Kedua. Lembaga Penelitian Universitas Negeri Makassar.

Ginting, R., Razali \& Nasution, Z. 2013. Pemetaan status unsur hara $\mathrm{C}$-organik dan nitrogen di perkebun nanas (Ananas comosus L. Merr) rakyat Desa Panribuan Kecamatan Dolok Silau Kabupaten. Jurnal Online Agroekoteknologi 1(4): 1308-1318.

Kabupaten Pinrang dalam Angka, 2015

Kecamatan Lanrisang dalam Angka, 2012.
Taufieq, Nur Anny S. 2005. Pemanfaatan limbah pabrik gula (blotong) sebagai pupuk organik. Jurnal Teknika 13 (1): 43-48.

Taufieq, Nur Anny S. 2006. Dampak limbah bahan organik terhadap lingkungan perairan. Jurnal MIPA dan Pembelajarannya Edisi Khusus: 115120.

Taufieq, Nur Anny S. 2010a. Pemanfaatan zeolit dan bokashi ampas tahu untuk menekan konsentrasi logam berat pada tanah podsolik merah kuning di Soroako. Jurnal Chemica 11 (1): 9-14.

Taufieq, Nur Anny S. 2010b. The utilization of zeolith and bokashi of tofu waste to improve of baby corn growth at ultisol soil in Soroako. Jurnal Teknosains 4 (2): 220-228.

Taufieq, Nur Anny S., Rahim, S.A. \& Jamil, H. 2013. Effectiveness of the bran media and bacteria inoculum treatments in increasing $\mathrm{pH}$ and reducing sulfur-total of acid sulfate soils. AIP Conference Proceedings 1571: 647-653. 